\title{
Pemikiran dan Perjuangan Anregurutta Haji Lanre Said (1923-2005)
}

\author{
Andi Makmur ${ }^{1}$, Mustari Bosra ${ }^{2}$, Bahri $^{3}$ \\ ${ }^{1}$ Pendidikan Sejarah Fakultas Ilmu Sosial Universitas Negeri Makassar, Indonesia \\ Email: makmurandi31@gmail.com
}

\begin{abstract}
Abstrak
Tulisan ini bertujuan untuk mengetahui apa yang melatar belakangi pemikiran dan perjuangan Anregurutta Haji Lanre Said, bagaimana pemikiran Anregurutta Haji Lanre Said, serta Perjuangan Anregurutta Haji Lanre Said.Prosedur dalam penelitian ini menggunakan metode sejarah dengan tahapan: Heuristik, Kritik, Interpretasi dan Historiografi. Hasil penelitian menunjukkan bahwa yang melatar belakangi pemikiran dan perjuangan Anregurutta Haji Lanre Said ialah pendidikan yang beliau dapat dari keluarga yang memang mencintai agama, serta pendidikan yang telah diperolehnya di pondok Pesantren As'adiyah Sengkang. Pemikiran Anregurutta Haji Lanre Said meliputi, pemikiran keagamaan, kenegaraan, dan pendidikan Islam. Beliau selalu menekankan kepada setiap muridnya untuk menjadikan Al'Qur'an dan Hadist sebagai pedoman utama dalam menjalankan syariat Islam. Selain itu beliau juga menekankan untuk tetap patuh terhadap pemerintah yang ada dan tetap bersikap netral tanpa memihak satu parpol tertentu. Keterlibatannya dengan gerakan DI/TII bukan karena beliau sepenuhnya setuju dengan gerakan tersebut, melainkan untuk melindungi keluarganya agar tidak tidak dipaksa untuk terlibat dalam gerakan tersebut. Dari hasil penelitian ini dapat disimpulkan bahwa pemikiran beliau tehradap pendidikan islam, keagamaan dan kenegaraan beliau peroleh dari lingkungan keluarga dan lembaga Pendidikan yang fokus terhadap agama. Setelah memutuskan untuk keluar dari gerakan DI/TII pada tahun 1961. Beliau melakuakan begitu banyak perjuangan, baik itu dalam mencari lokasi untuk mendirikan Pondok Pesantren Darrul Huffadh hingga perjuangan untuk mempertahankan Pondok Pesantren tersebut.
\end{abstract}

Kata Kunci: Anregurutta, Pondok Pesantren, Darrul Huffadh

\begin{abstract}
This this study aims to find out what lies behind the thoughts and struggles of Anregurutta Haji Lanre Said, how the thoughts of Anregurutta Haji Lanre Said, and the Struggle of Anregurutta Haji Lanre Said. The procedure in this study uses historical methods with stages: Heuristics, Criticism, Interpretation and Historiography. The results showed that the background of the thoughts and struggles of Anregurutta Haji Lanre Said was education that he got from families who really loved religion, and the education he had obtained in the Sengkang As'adiyah Islamic Boarding School. The thoughts of Anregurutta Haji Lanre Said include, religious thought, statehood, and Islamic education. He always emphasizes to each of his students to make Al'Quran and Hadith the main guideline in carrying out Islamic law. In addition, he also stressed to remain obedient to the existing government and remain neutral without taking sides for certain political parties. His involvement with the DI / TII movement was not because he fully agreed with the movement, but rather to protect his family so that he was not forced to become involved in the movement. From the results of this study it can be concluded that his thoughts on Islamic, religious and state education were obtained from the family environment and educational institutions that focused on religion. After deciding to leave the DI / TII movement in 1961. He carried out so many struggles, both in finding locations to establish Darrul Huffadh Islamic Boarding School to the struggle to maintain the Islamic Boarding school
\end{abstract}

Keyword : Anregurutta, Islamic Boarding School, Darrul Huffadh 


\section{A. Pendahuluan}

Islam masuk ke Nusantara membawa misi pendidikan dengan menyampaikan ajaran agama kepada penduduk. Penyampaian tersebut dilakukan di sebuah tempat pendidikan Islam tradisional yang dikenal dengan istilah Pondok Pesantren. Sebuah pondok pesantren terdiri dari seorang guru pemimpin, umumnya seorang haji, yang biasa disebut dengan kyai (istilah umum di Indonesia) dan sekelompok murid yang jumlahnya bervariasi, ada yang dibawah sepuluh murid sampai dengan ribuan murid yang biasa disebut dengan istilah santri. Berdirinya pondok pesantren tidak perlu menunggu banyak tenaga ahli untuk memulai kegiatan pembelajaran. Bahkan cukup dengan seorang kyai, sebuah pesantren sudah dapat dirintis, didirikan dan memberi banyak manfaat bagi umat manusia. Demikian pula dengan santri sebuah pesantren dapat dirintis meski santrinya hanya berjumlah tujuh orang atau lebih.

Seorang ulama yang digelari sebagai kyai memang dipandang sebagai penerus nabi dalam mensyiarkan agama Islam. Dalam dunia pesantren, kyai merupakan pimpinan pondok pesantren, akan tetapi kepemimpinannya bukan hanya diperuntukan bagi santrinya, tapi bagi seluruh masyarakat Islam di dalam atau luar lingkungannya. Hal ini bisa dibuktikan dengan adanya ceramah dari desa ke desa maupun dari wilayah ke wilayah lain. Maka, kebenaran akan ulama sebagai pewaris nabi tidak dapat dinafikan, terlebih di zaman sekarang yang serba modern, atau masyarakaat yang hidup dalam demokrasi, sosok kyai dipandang sebagai panutan sekaligus tauladan bagi masyarakat Islam. Istilah "Kyai" berasal dari bahasa Jawa.Kata kyai mempunyai makna yang agung, keramat, dan dituakan. Selain gelar kyai diberikan kepada seorang laki-laki yang lanjut usia, arif, dan dihormati.

Gelar kyai juga diberikan untuk bendabenda yang keramat dan dituakan, seperti keris dan tombak. Di Sulawesi Selatan kata kyai, sepadan dengan kata anregurutta
(Bugis) atau anronggurutta (Makassar) yang bermakna Guru Kita. Dari segi istilah ,anregurutta adalah seseorang yang memiliki keilmuan dalam bidang agama yang tinggi dan memiliki prilaku (ampeampe) yang baik (madeceng). Dengan demikian hanya ulama saja yang bisa disebut anregurutta, panggilan tersebut adalah legitimasi dari masyarakat sendiri yang memberi pengakuan terhadap ulama yang telah sampai derajatnya pada level anreguruta. Bertolak dari hal tersebut diatas, maka penulis tertarik untuk membahas lebih lanjut mengenai "Pemikiran Dan Perjuangan Anregurutta Haji Lanre Said (1923-2005)”. Beliau merupakan pendiri dan pemimpin pondok pesantren Darul Huffadh sampai pada tahun 2005, tahun dimana beliau wafat. Pada tanggal 7 Agustus 1975 Anregurutta Haji Lanre Said mendirikan Pondok Pesantren Darul Huffadh yang merupakan realisasi dari petunjuk Allah S.W.T melalui mimpi yang dialaminya pada tahun 1962 . Mimpi itu kemudian Dita'birkan (diartikan) sebagai perintah mendirikan sebuah lembaga pesantren yang khas untuk penghafalan Al-Qur'an dan ilmu-ilmu agama Islam dengan proses pendirian dan pelaksanaannya bersandar melalui tata cara dan garis-garis ketentuan yang tertera dalam kandungan mimpi tersebut.

Jurnal ini berbeda dengan jurnal terkait lainnya dimana dalam jurnal ini Anregurutta Haji Lanre Said mempunyai Pemikiran yang tergolong unik tentang pendidikan Islam, karena pondok pesantren Darul Huffadh yang beliau dirikan, dari awal berdiri hingga sekarang tidak memungut biaya dari santri, serta tidak meminta sumbangan dari masyarakat dan tidak mementingkan kepentingan pribadi di atas kepentingan pesantren, bahkan semua biaya selama menjadi santri di pondok tersebut diusahakan oleh pimpinan Pondok Pesantren itu sendiri inilah yang menjadi pembeda penulisan jurnal ini dengan jurnal serupa lainnya. Adapun data yang didapatkan dari penulisan jurnal ini berasal dari metode 
kualitatif, berupa studi pustaka yaitu, berasal dari buku-buku terkait dan skripsi, yang kemudian diperkuat dengan melakukan wawancara dengan pihak keluarga.

\section{B. Metode Penelitian}

Metode Penelitian ini merupakan penelitian sejarah yang tentunya menggunakan metodologi sejarah dalam proses pengerjaannya:

\section{Heuristik.}

Merupakan tahap awal dalam penelitian sejarah. Dalam tahap ini penulis diwajibkan mecari data terkait penelitian yang dilakukan sehingga tentunya membutuhkan waktu, biaya serta tenaga yang tidak sedikit (Helius Sjamsuddin, 2012). Dalam proses pengumpulan data selain mengunjungi berbagai perpustakaan untuk mencari data tertulis baik berupa skripsi, buku, tesis maupun karya ilmiah lainnya. Penulis juga melakukan penelitian lapangan dengan melakukan wawancara terhadap anak Lanre Said maupun kepada santrinya serta peneliti yang pernah dan sedang melakukan penelitian terhadap beliau, seperti sa'diah said, Dr. Ilham Kadir, Ust Tahang, Dr. Muslimin A.R. Effendy,MA. Selanjutnya, penulis melakukan kritik baik kritik ekstern dan kritik intern, interpretasi (penafsiran sumber) dan historiografi (penulisan sejarah). Metode pengumpulan data dilakukan dengan cara melakukan penelitian lapangan (wawancara, pengamatan) dan penelitian pustaka terutama di Pondok Pesantren Darrul Huffadh.

\section{Kritik.}

Setelah data-data terkumpul, langkah selanjutnya yaitu melakukan kritik sumber terhadap data yang telah ditemukan. Aspek yang dikritik yaitu mengenai keaslian dokumen dan juga mengenai tingkat kebenaran informasi sehingga dapat dihasilkan sebuah karya yang sesuai dengan apa yang menjadi pokok kajian dalam tulisan ini.

\section{Interpretasi.}

Tahap selanjutnya itu interpretasi. Data yang tadinya telah di lakukan kritik sumber sebenarnya hanya bersifat data sehingga pada tahap inilah diperlukan kecermatan penulis untuk bisa membuat data-data ini memiliki nyawa sehingga bisa terasa hidup dan memiliki makna. Dalam proses interpretasi penulis tentunya harus mampu mengimbangi dirinya sehingga tulisan itu nantinya tidak berat sebelah. Karena penulis haruslah netral dan menulis sesuai dengan apa yang ia temukan dilapangan

\section{Historiografi.}

Merupakan tahap akhir dari penelitiaan sejarah. Dalam tahap ini data-data yang tadinya telah diinterpretasikan kemudian dirangkai kata-kata demi kata sesuai data sehingga dapat menjadi tulisan sejarah yang dapa disuguhkan secara kronologis.

\section{Tinjauan Penelitian}

Pada dasarnya, penelitian tentang pemikiran dan perjuangan seorang tokoh atau ulama sudah ada beberapa orang yang melakukannya, baik berupa karya dalam bentuk artikel maupun media massa dan media sosial.

Adapun karya ilmiah ataupun artikal yang ditemukan oleh penulis terkait tentang tokoh atau ulama yaitu: buku yang berjudul "ETTA" Meniti di Dalam Cahaya. Yang di susun oleh: Sabri AR dan kawan-kawan. Isi dari buku tersebut menceritakan tentang bagaimana kisah hidup Anregurutta Haji Lanre Said hingga wafat. Buku ini juga menceritakan keterlibatan Anregurutta Haji Lanre Said dengan DI/TII hingga akhirnya mendirikan pondok pesantren Darul Huffaddh Tuju-Tuju.(Sabri, 2015). Adapun pembahasan yang akan dikaji oleh penulis adalah Pemikiran dan Perjuangan Anregurutta Haji Lanre Said.

D. Hasil dan Pembahasan

1. Pemikiran Keagamaan Anregurutta Haji Lanre Said

Pemikiran keagamaan Gurutta Haji Lanre Said dalam pandangan putra sekaligus anak didik pertamanya, DR. KH. 
Muttaqin Said adalah perpaduan antara sufi-salafi, pemahaman beliau dalam aliran sufi termasuk kental, ini bisa dilihat dari banyaknya ritual-ritual zikir khusus yang beliau amalkan selama hidupnya dan zikirzikir tersebut semuanya memiliki maksud dan tujuan tertentu. (Anon., 2016) Salah satu fungsi zikir dalam amalam para sufi adalah mengasah mata batin, pada tahaptahap tertentu dapat menyentuh level kasyful mughayyabat atau dapat mengetahui hal-hal yang bersifat ghaib terutama perkara-perkara yang akan terjadi. Gurutta Haji Lanre Said termasuk dalam kategori ini, sebagai contoh, ketika beliau diberi mimpi berisi perintah dan petunjuk untuk mendirikan lembaga pendidikan yang kemudian menjadi kenyataan. (kadir, 2012)

Jenis tasawuf yang diamalkan Gurutta Lanre Said adalah tasawwuf akhlaqiy yaitu jenis ajaran tasawuf yang mengambil dari dimensi ahlak, lebih tepatnya ajaran tasawuf secara subtansial seperti, mengedepankan keikhlasan, sabar dalam menghadapai segala bentuk cobaan, tekun beribadah, mengedepankan kesederhanaan, mendidik dengan sepenuh jiwa, mengedepankan kepentingan umum dibanding kepentingan diri dan keluarga.

Pemahaman salafi yang dimaksud di sini adalah, mengamalkan ajaran Islam sebagaimana yang telah diamalkan oleh Rasulullah dan para sahabat-sahabatnya, lalu turun kegenerasi berikutnya yang disebut para tabi'in (pengikut sahabat Nabi), dan tabi'ut tabi'in (para pengikut tabi'in). Mereka inilah yang disebut sebagai khaerul qurun sebaik-baik masa. Para imam mazhab, Abu Hanifah, Malik bin Anas, Imam Syafi'i, dan Ahmad bin Hambal adalah masuk dalam kategori sebagai para ulama salaf yang ajarannya menjadi muara pada para penganut Islam Ahlussunnah wal Jamaah saat ini.

a. Santri Pondok Pesantren Darul Huffadh tidak diperkenankan merokok selama menjadi santri.

b. Santri/wati Pondok Pesantren Darul Huffadh tidak dibenarkan berkunjung kerumah penduduk anpa seizin Pimpinan Pondok Pesantren.

c. Santri/Wati Pondok Pesantren Darul Huffadh tidak diperbolehkan mengadakan ceramah-ceramah tanpa sepengetahuan Pmpinan Pondok Pesantren. (Al \& Saíd, 2014)

\section{Pemikiran Tentang Kenegaraan}

Pada 7 Agustus 1953, Komandan Tentara Keamanan Rakyat (TKR) di daerah Sulawesi Selatan Abdul Qahhar Muzakkar memproklamasikan penggabungan pasukan dan daerah yang dikuasainya ke dalam Negara Islam Indonesia (NII) dibawah pimpinan Kartosuwirjo yang berpusat di Jawa Barat. Dengan bergabungnya Qahhar Muzakkar ke dalam NII, secara otomatis jaringan NII yang telah diproklamirkan Kartosuwirjo pada 7 Agustus tahun 1949 bertambah luas. (Gonggong, 2004)

Untuk menopang perjuangan NII, Kartoswirjo membentuk angkatan bersenjata yang diberi nama Gerakan Darul Islam/Tentara Islam Indonesia (DI/TII) yang digunakan untuk

eksistensinya, termasuk menentang pasukan dan pemerintahan Republik Indonesia yang tidak setuju tentang perjuangan, visi, dan misi NII. Diperkirakan pada tahun 1953, setelah dua tahun merintis sekolah dan mengajar di Pulau Jampea, Selayar (1951-1953), dan bertepatan pada tahun diproklamasikannya penggabungan pasukan Qahhar Muzakkar dan pasukan yang dikuasainya ke dalam NII, Lanre Said bergabung bersama DI/TII dibawah pimpinan Qahhar Muzakkar. Selain karena teman-teman yang pernah belajar di MAI Sengkang telah lebih dulu bergabung dalam gerakan tersebut, faktor keluarga juga menjadi alasan Anregurutta Lanre Said terlibat dalam gerakan tersebut.

Meskipun tidak pernah membenarkan bahwa beliau sepakat dengan pejuangan yang dilakukan oleh Qahar Mudzakkar, 
namun jabatan yang pernah diemban sebagai anggota komando pusat yang mengambil keputusan-keputusan yang diterapkan di daerah Komando Wilayah Tenggara Tengah dan Utara (KWTUU), juga sebagai Ketua Pengadilan Komando Daerah (KD) dapat menjadi alasan bahwa Anregurutta Haji Lanre Said sejalan dengan perjuangan DI/TII dalam hal menegakkan hukum Syariat. Meskipun pada akhirnya memilih untuk keluar dan kembali mengajarkan agama kepada masyarakat.

Untuk membaca dan menelaah pemikiran kenegaraaan Anregurutta Haji.Lanre Said dapat kita temukan dalam asas-asas aturan dan ideologi pondok pesantren Darul Huffadh yang beliau dirikan. Asas-asas tersebut masyhur disebut dalam pondok sebagai Undang-undang Dasar Pondok Pesantren Darul Huffadz beberapa poin diantaranya ialah:

a. Pondok Pesantren Darrul Huffadh tetap bernaung dibawah pemerintahan yang berasaskan pancasila dan UndangUndang Dasar 1945 selama dasar berada dalam kemurniannya.

b. Pondok Pesantren Darrul Huffadh tidak terikat dengan salah satu partai politik atau organisasi-organisasi massa lainnya.

Dua poin diatas membuktikan bahwa Anregurutta Haji Lanre Said meskipun pernah terlibat aktif dalam gerakan DI/TII tetaplah negarawan yang mengakui Pancasila dan Undang-Undang Dasar 45 sebagai dasar negara.

\section{Pemikiran Tentang Pendidikan Islam}

Pemikiran pendidikan Islam sejatinya telah melahirkan gagasan dalam regenerasi ulama, tidak terkecuali ulama Bugis. Pemikiran pendidikan terus berkembang untuk merespons masalah-masalah internal dan eksternal. Dari dalam para tokoh pendidikan berusaha mengembangkan pendidikan Islam dengan berbagai dinamika yang ada, menguatkan fondasifondasi peserta didik, khususnya terkait materi pengembangan akidah dan syariat agar mereka tetap kokoh memegang teguh keyakinan. Dari luar, berusaha beradaptasi dengan baik, menahan perkembangan globalisasi, menyaring setiap sistem yang ada, lalu menyerap dan menerapkan jika dianggap perlu. (Rasmin, 2018)

Agama dan ilmu pengetahuan merupakan tujuan utama pendidikan. Agama berbasis kepada pendidikan yakni nilai-nilai etik-moral, dan ilmu pengetahuan merupakan pengembangan keahlian. Kedua komponen tersebut berproses dalam sejarah sehingga terjadi dinamika yang begitu pesat. Pada dasarnya krakteristik dasar pemikiran Islam mengenai pendidikan Islam, cenderung bersifat organik, sistematis dan fungsional dengan akar paradigma yang mengacu pada Al-Quran, Al-Sunnah dan ijtihad. (Pandiklis, 2011)

Para ulama Bugis sejak dulu dikenal sebagai peletak dasar-dasar pendidikan Islam. Mereka merespons dengan baik setiap pergantian zaman, serta tetap menjadi bagian penting dalam membangun bangsa lewat dunia pendidikan dengan mencerdaskan kehidupan bangsa dan membangun masyarakat beradab.

Sebagai salah satu ulama yang mencinta pendidikan berbasis Islam Anregurutta Haji Lanre Said beranggapan bahwa, pendidikan Islam yang tepat adalah pendidikan yang menekankan pada aspek akidah yang benar yakni ahlussunnah waljimah dan tidak boleh sejalan dengan ahli bid'ah lainnya. Seperti Bid'ah akidah sebagaimana yang di dakwahkan oleh ahmadiyah, islam jama'ah, dan syiah. Dari segi syariat pendidikan harus bertujuan mengamalkan syariat yang merujuk pada al-qurán dan hadist sahih, harus jauh dari segala bentuk bid'ah dalam hal-hal ibadah.

Semasa hidup, dalam setiap kesempatan beliau menekankan bahwa saat ini adalah masa yang tersulit bagi umat Islam, terutama yang berada di pedalaman. Ini terjadi karena para ulama, cendekiawan, penyuluh agama berlomba-lomba masuk ke kota untuk mengejar kemewahan dan hidup senang. Disaat yang sama orangorang yang berada di pedalaman justru mengalami ketertinggalan dalam 
memahami agama. Hal inilah yang menjadi latar belakang beliau mengatakan bahwa pendidikan islam adalah pendidikan dasar yang harus di ajarkan sejak dini untuk menjadikan manusia menjadi lebih beriman, beramal saleh, dan berperilaku saling mengingatkan dalam hal kebenaran.

Selain itu, menurut Anregurutta Haji Lanre Said pendidik juga harus memiliki rasa tanggung jawab dan ikhlas. Keikhlasan untuk mendidik tanpa harus diberi imbalan karena "Ikhlas" inilah sebenarnya hakikat dari pendidikan. Jadi pendidikan adalah sesuatu yang dilakukan dengan ikhlas. (Said., 2018)

Untuk mengetahui lebih lanjut pemikiran Anregurutta Haji Lanre Said tentang pendidikan islam, berikut hasil pemikirannya yang diterapkan di pondok pesantren Darrul Huffadh

\section{a. Tujuan Pendidikan Islam}

Sebagai salah satu Ulama Bugis yang sangat mencintai pendidikan berbasis Islam, Anregurutta Haji Lanre Said mendirikan pondok pesantren yang bertujuan untuk mencetak generasi pelanjut yang mampu melahirkan manusia saleh, beradab, tangguh dalam berjuang, memiliki pemahaman keagamaan yang berdasarkan dengan apa yang telah diajarkan oleh Nabi Muhammad S.A.W. (Muslimin, 2018) Untuk mencapai tujuannya tersebut, Anregurutta Haji Lanre Said mewajibkan kepada setiap santri untuk menghafal alqurán (tahfizhul Qurán) sesuai dengan kaidah-kaidah tajwid, mengajarkan dan memahamkan ilmu-ilmu alat yang berhubungan dengan al-Qur'an, seperti pelajaran Ulumul-Qur'an yang di dalamnya terdapat berbagai jenis ilmu, seperti nasikh wal mansukh, asbabun nuzul, al-qira'ah assab'ah dan lain-lain. (Said., 2018)

Pendidikan tahfizhul qur'an bagi Anregurutta Haji Lanre Said adalah untuk memasyarakatkan Al-Qur'an. Dengan hidupnya budaya hafal Al-Qur'an maka umat Islam tidak akan susah diajak berlayar ke pulau Al-Qur'an. Yang dimaksud Lanre Said dengan pulau Al-Qur'an adalah mewujudkan tatanan masyarakat yang hidup dengan Al-Qur'an. Masyarakat qur'ani adalah mereka yang menjadikan kitab suci sebagai ukuran benar salahnya sebuah tindakan. Pulau Al-Qur'an adalah negara yang merujuk pada Al-Qur'an dalam segala bentuk kehidupannya Menurutnya Dengan penguasaan terhadap al-Qur'an dan perangkat-perangkatnya, maka secara perlahan seorang santri akan dapat mencapai gelar ulama, karena dibekali dengan hafalan Al-Quran. (Kadir', 2014)

Kalau para santri dan pelanjutnya kemudian tidak memahami tujuan pondok yang beliau ibaratkan sebagai kapal, maka susah untuk mencapai tujuan mulia itu. Lanre Said berharap agar segenap anak didiknya siap berlayar ke pulau al'qurán dan hadis sahih sebagaimana di contohkan nabi dan salafussaleh. (Kadir, 2019.)

\section{b. Sistem Pendidikan Islam}

Pendidikan Islam mampu mengakomodasikan tuntutan hidup manusia dari zaman ke zaman, termasuk tuntutan di bidang ilmu agama dan teknologi. Pesantren sebagai salah satu lembaga pendidikan Islam yang telah mampu mengakomodasikan keinginan jati dirinya dalam mencetak generasi-generasi penerus Islam yang cakap dan terampil serta menguasai berbagai ilmu pengetahuan dan teknologi. (arifin, 1991)

Demikian pula dengan Pondok Pesantren Darul Huffadh yang didirikan oleh Anregrutta Haji Lanre Said, beliau telah menerapkan sistem pendidikan sebagaimana yang tersebut diatas. Dalam kaitannya dengan sistem pendidikan, dari awal pendiriannya Pondok Pesantren Darul Huffadh telah menerapkan sistem pendidikan formal dan non formal. Sistem pendidikan non formal yang dimaksud seperti, mengadakan pengajian-pengajian, keterampilan agama berupa praktek ibadah di luar kelas yang terikat pada kurikulum. (Heriadi, 2015)

\section{1) Metode Pendidikan Islam}

Sejak awal Anregurutta Haji Lanre Said telah menanamkan ilmu, ibadah, dan amal yang benar kepada segenap santrinya. Perkara-perkara bidah akidah dan ibadah 
telah beliau tuangkan dengan baik melalui tulisan-tulisannya dalam buku Adz-Dzikra. Dalam mendidik, Anregurutta Lanre Said menggunakan beberapa metode seperti:

a) Metode Ceramah, umumnya Ust Lanre Said menggunakan metode ceramah kalau para santri-santri dan jamaah masjid yang dihadapi. Tapi kalau untuk kalangan internal seperti para guru maka metodenya diskusi dan interaktif. Beliau dalam mengajar sangat dinamis melihat siapa yang diajar tergantung level muridnya.

b) Metode Hafalan, metode yang digunakakn beliau, untuk menjaga hafalan Qu,ran. Jika sudah hafal, santri di wajibkan untuk menyetor hafalnnya yang disebut dengan istilah Mappangolo. (Ilham Kadir, 2008)

c) Metode Keteladanan, metode yang memberikan teladan atau contoh yang baik kepada peserta didik dalam kehidupan sehari-hari.

Artinya, peserta didik tidak hanya duduk di kelas dan diam memperhatikan gurunya begitupun dengan guru, guru tidak hanya menjelaskan, namun mereka di wajibkan untuk menerapkan ilmu yang diperoleh dalam kehidupan sehari-hari. Karena menurut beliau, seorang pendidik, pemimpin, ulama, ataupun orang tua harus mampu menyelarsakan apa yang dikatakan dengan apa yang di lakukan khususnya bagi pendidik yang berada di lingkungan lembaga pendidikan yang berbasis agama. (kadir, 2018) Metode Pembiasaan, yaitu membiasakan peserta didik (santri) melakuakan segala sesuatu sejak masuk di pondok.

\section{c. Kurikulum Pendidikan Islam}

Berkenaan dengan kurikulum, Anregurutta Haji Lanre Said sejak resmi menjadi lembaga pendidikan, pesantren yang beliau dirikan (Darul Huffadh) menekankan adanya kurikulum yang mampu mendekatkan diri kepada Allah SWT seperti:

1) Berusaha menegakkan kalimat Allah swt.
2) Berusaha menghidupkan ajaran Alquran dan tuntuan hadits shahih dengan memperagakan dalam praktek hidup sehari-hari.

3) Berusaha ikut srta membangun moral dan mencerdaskan generasi bangsa.

4) Berusaha memberantas buta baca Alquran.

5) Berusaha mencetak hafidz da hafidzah yang memiliki bobot kwalitas moral spritual, berwawasan luas, sanggup berkorban untuk agama.

6) Berusaha mengangkat kaum mustadl'afiin dari anak yatim dan golongan fakir miskin melalui lembagalembaga pendidikan Islam secara cumacuma.

Selain itu, beliau juga memasukkan kegiatan-kegitan non ilmu teoritik seperti

1) Mustawa/TPA/TQA, program belajar khusus para santri yang tinggal di sekitar pesantren dan masih terlibat dengan akademis.

2) Tahfidzul Qurán, menghafal al-Qurán adalah aktifitas inti yang dijalankan oleh pesantren.

3) Kuliyyatul Muállimin al-Islamiyah, program studuy di KMI ini setingkat Tsanawiyah dan Aliyah.

\section{E. Kesimpulan}

Pemikiran dan Perjuangan yang dilakukan oleh Anregurutta Haji Lanre Said dilatarbelakangi oleh pendidikan yang telah diperolehnya di pondok pesantren As'adiyah Sengkang. Dimana dalam pendidikan itu, Kiyai As'ad selalu menekankan kepada santri-santrinya pentingnya mengamalkan ilmu yang diperoleh. Selain itu, hal yang melatar belakangi pemikiran dan perjuangan Anregurutta Haji Lanre Said adalah kecintaannya terhadap dunia pendidikan serta keinginannya untuk menanamkan nilai-nilai agama kepada masyarakat. Faktor lainnya ialah, karena Anregurutta Haji Lanre Said besar dalam asuhan kedua orang tua yang sangat mencintai ilmu agama. 
Pemikiran Anregurutta Haji Lanre Said meliputi, pemikiran keagamaan, pemikiran kenegaraan, dan pemikiran pendidikan Islam.

\section{F. Daftar Pustaka}

Al \& Saíd, U. S., 2014. "Serba-Serbi 33 Tahun Pondok Pesantren Darul Huffadh. s.l.:General Information.

Anon., 2016. read/663851/71/gurutta-hlanre-said-bangun-pesantren-gratisïhabis-1344385218/13),. [Online] Available at: https://ramadan.sindonews.com [Accessed 25 januari 2019].

arifin, M., 1991. Filsafat Pendidikan Islam. Jakarta: Bina Aksara.

Gonggong, A., 2004. In: Abdul Qahhar Muzakkar, dari Patriot hingga Pemberontak. Jakarta: Ombak.

Kadir', I., 2014. 'KH LANRE SAID: Ulama Pendidk Dari DI/TII Hingga Era Reformasi, enrekang: STKIP.

Kadir, I., 2019.. wawancara [Interview] (15 Januari 2019.).

kadir, I., 2012. ,AnreGurutta Lanre Said: Ulama bugis yang visioner. Refleksi Ulang Tahun ke-37 Pondok Pesantren Darul Huffadhz.

kadir, I., 2018. Pondok Putri Pesantren Darrul Huffadh Tuju-Tuju [Interview] (18 JULI 2018).

Muslimin, 2018. pemikiran dan perjuangan Lanre Said [Interview] (3 Desember 2018).

Pandiklis, 2011. Pemikiran Pendidikan Islam Menurut Muhammad Abduh (Kajian Filsafat Pendidikan Islam dalam Aspek Epistemologi). In: Malang : s.n.

Rasmin, M. Z., 2018. Pendidikan Islam Dalam Perspektif Ulama Bugis K.H. LANRE SAID. " Tadibuna, Volume 7, p. 61.

Sabri, D., 2015. ETTA"Meniti dalam Cahaya". In: M. J. Nur Najma Marzuki, ed. Buku. Makassar: Daffa Publishing.
Said., S. L., 2018. KH, Lanre Said secara umum [Interview] (18 Juli 2018). 